\title{
Representation of Beauty Standards in Films Imperfect: Career, Love \& Scales
}

\author{
Miechel Valencia ${ }^{1}$ Ahmad Junaidi ${ }^{{ }^{*}}$ \\ ${ }^{1}$ Faculty of Communication, Universitas Tarumanagara, Jakarta 11440, Indonesia \\ *Corresponding author. Email: ahmadd@fikom.untar.ac.id
}

\begin{abstract}
This study aims to describe the representation of beauty standards in the film Imperfect: Career, Love \& Scales by director Ernest Prakasa. This research uses a qualitative approach. The method used in this research is semiotics, the semiotics theory used is John Fiske's semiotics by analysing the three levels that exist in John Fiske's semiotics. The subject of this research is the film Imperfect: Career, Love \& Scales, the object of this research is the signs of beauty standards in the Imperfect film: Career, Love \& Scales represented in dialogue, scenes, and characters in the film. Data collection techniques used in this study were interviews, observation, literature study, and documentation. Imperfect film: Career, Love \& Scales tells the standard of beauty that forces Rara to change her appearance to get a position that matches her intelligence. The results of this study were analyzed using three levels in John Fiske's theory of semiotics, the first is the level reality. At this level seeing the reality of appearance, in this film, it can be seen from the aspects of Appearance, Dress (Costume), Make Up, Environment, Expression, Behavior, Speech, and Dialogue. Both levels of representation, this level display technical codes. In this film, it is seen from the shooting category with techniques close up and long shots. As well as the lighting category low key and high key. The three levels of ideology, this level categorizes all the elements that are in signs. Imperfect film contains a patriarchal ideology with demands for feminism.
\end{abstract}

Keywords: Beauty standard, John Fiske Semiotic, Film

\section{INTRODUCTION}

Communication is a process to obtain information in the form of messages carried out by two or more people, one of which is the sender of the message (communicator) and the other is the recipient of the message (communicant). Mulyana [1] The communication process is the process of conveying thoughts or feelings by someone (communicator) to others (communicant). Thoughts can be ideas, information, opinions, etc. that arise from his mind. One form of communication is mass communication. Several components of mass communication, namely mass communicators or people who produce, mass messages and convey it through mass media and cannot see, audiences mass whose numbers are always changing because of the messages conveyed by the communicators indirectly, and the process in which the message reaching the audience through the mass media which is called mass communication [2]. Communication experts place limits on mass communication on communications using mass media, for example newspapers, magazines, radio, television, or films. The characteristics of mass communication are one-way mass communication, the communicator is institutionalized, the message is general, the media creates synchronization, and the communicants are heterogeneous [1]. One form of mass media is film. Film is a new form of mass media that emerged in the 19th century, but is still rarely used. Later film became the presentation and distribution tool of an older entertainment tradition, offering stories, stage, music, drama, humor and technical tricks for popular consumption. Mc Quail [3] Films are true mass media, which means that films can reach audience a very wide quickly. Eden and Juni [4] Films can also be used as an alternative means of conveying thoughts about the restlessness of the surrounding environment, as well as being used for education. The way to educate from the film is to take the message contained in the film. Melisa et al [5] film is a representation and reality of people's daily life. In addition, films are also made by reshaping reality in the form of codes, conventions, and ideologies from the culture of the people that are shown on the big screen. The form of representation can be in the form of writing, conversation, and also in audio visual form. Representation is something that focuses on the issues raised so that it looks natural. Film can be raised about the unrest that exist around the life of the community, one of the concerns that many feel is the standard of beauty in women. According to Meliana (2006) beauty is always standardized by a slim body, firm breasts, curvy waist, and plump buttocks. According to Kasiyan (2008) beauty is synonymous with white, firm, and smooth skin, and a body shape that accentuates the curvature and hair loss of certain 
organs [5]. To adjust to today's beauty standards, many women make changes to their bodies, from treatments to extreme measures, namely performing various operations. The efforts made by women to look beautiful are caused by two factors, starting from internal factors and external factors. Internal factors are caused by psychological disorders ranging from narcissism and BDD (syndrome Body Dysmorphic Disorder), while external factors are work, environment, and demands of people around them. Beauty and the physical form of women are interconnected and inseparable. This is reinforced by the appearance of media content that portrays women's beauty by presenting a beautiful physical form[6]. In 2019 the film Imperfect, directed by Ernest Prakasa and also written by Meira Anastasia, was shown. film Imperfect has a strong theme regarding insecurity and how a person has a body image. This film also raises issues that are very close to our daily lives such as body shaming, cyber bullying, and other things. This film tells the story of Rara, who often comes under pressure from her surroundings. Rara was considered unsightly because she was fat, had brown skin, and had thick curly hair. Since childhood, Rara has received body shaming from her mother, besides that in her office environment, Rara is required to look like a woman in general. Has a slim body, white skin, and has straight black hair[7]. The messages that want to convey Imperfect are very strong and can be easily taken as students in living their daily lives. The appearance of current media content makes people willing to change their face and body shape to be accepted by the surrounding environment, because the environment has its own beauty standards. Beauty standards are a very sensitive issue to discuss because it has become a culture that exists in society to standardize and give an assessment of one's appearance, but in the film, it is Imperfect shown how the attitudes and opinions of people around who are less pleasant towards someone who makes changes to adjust themselves so that it is the same as the beauty standards that exist in the community. The writer and director of this film believes that beauty standards are very important issues to be raised to a wider stage. Turner in Irwanto[5], film is a representation and reality of everyday people's life. In addition, films are also made by reshaping reality in the form of codes, conventions, and ideologies from the culture of the people that are shown on the big screen. The form of representation can be in the form of writing, conversation, and also in audio visual form. Representation is something that focuses on the issues raised so that it looks natural. Based on the background of the problems that have been described, the authors are interested in conducting research on "Representation of Beauty Standards inFilms Imperfect".

extend the rule to verify an $n$-component system $(n \geq 2)$. Through several large cases, it is shown that our improvements are feasible and efficient.

\subsection{Related Work}

\subsubsection{Free Sex Representation in Dangdut Song Lyrics (Semiotic Analysis of Saussure on "Cinta Satu Malam" Song Lyrics)}

The social reality examined in the song is the pattern of free sex behavior among the community through song lyrics. The language used explicitly represents the phenomenon of free sex as a social reality and also shows a shift in the value of language, especially the words in dangdut songs. The similarity of this research with the research that the writer takes is the same as seeing the social reality that exists in the environment besides that the other equation is using the same method, namely by doing semiotics. The difference between this study and the research that the writer took was that the theory used was different, this study used Saussure's semiotic theory, while the writer used John Fiske's semiotic theory. Another difference is that this research does semiotics on the song lyrics while the writer does semiotics on the film.

\subsubsection{John Fiske's Semiotic Analysis on Gender Bias in the Adhan Ayah Version of the Ramadan Adhan Line}

Based on the analysis through the level of reality, in the display code, clothing, gesture, expression, conversation, voice, and text, it can be seen that the online version of the father's adhan contains the reality of gender bias. Showing the difference between the female figure and the male figure. The similarity with the research that the author is doing is the same using John Fiske's theory of semiotics. The difference with the research conducted by the author is the difference between the objects used as research material, in which the authors conduct research on the representation of beauty standards in films, whereas this research focuses on gender bias in advertising.

\section{BACKGROUND}

\subsection{Mass Communication}

Romli [8] Mass communication is the activity of communicating messages to a large number of audiences using mass media. The most prominent characteristic of mass communication is that the messages received by the audience are difficult to understand, general in nature, the audienceis heterogeneous, and the message distribution is broad and difficult to control. The scope of mass media consists of newspapers, radio, films, as well as social media that work online, for example Facebook, Twitter, and others. The function of mass communication itself according to Dominick in (Ardianto, 2007) is a function of interpretation, the mass media not only provides data and facts, but interprets important events, provides value functions, provides views that the media hopes can 
influence the audience, and finally the entertainment function which is useful for entertaining the audience [2].

\subsection{Film as Mass Media}

Mc Quail [3] Film is a form of mass communication that has developed since the 19th century, film is an almost perfect mass media. Films are able to reach a wide audience, ranging from audiences in rural areas to those in urban areas. Films always raise themes or phenomena that grow and develop in people's lives and are projected onto the screen, films are also expected to influence and shape society based on the messages in the film. For the film director is a tool to convey messages to society [9] According to McQuail, in his book on film semiotic analysis and communication, there are several important themes that lead to film as a mass communication medium. First, films are used as a tool for propaganda, this is due to the ability of films to convey messages to a wide audience in a short time, in films there are ideologies that are packaged in the form of dramas or stories. The ideology in a film can spread if the audience watches a film whose story theme is close to social phenomena that exist in people's lives. Second, the emergence of new types of film art and the emergence of social documentary films.

\subsection{Representation}

According to Barker in the book Cultural Studie (2015), representation is an activity of how the world is socially constructed and represented by the audience and the audience itself [10]. In his introductory book, understanding media semiotics (Danesi, 2010) states that representation is something that cannot be separated from conveying messages in the media. Representation in the media is also defined as the use of signs (images, sounds, etc.) to redisplay something that is perceived, sensed, imagined, and felt in physical form [11]. Hall in the book Representation, Meaning, and Language on Representation, Cultural, Representation and Signifying Practice. London: Sage Publication (1997) defines representation as a process of changing the abstract ideological concept in its real form. Representation is a process used in the social process of meaning through the available tagging systems, such as video, dialogue, text, film and photography. It can be said that representation is the process of seeing signs through language [5].

\subsection{John Fiske Semiotic}

Semiotics as a model of social science understands the world as a system of relationships that has a basic unit called a 'sign'. In other words, semiotics study the essence of the existence of a sign[5]. The study of signs and the way they work is called semiotics or semiology. John Fiske outlines three main areas of study in semiotics, namely the sign itself, the code or system that organizes signs and the culture in which codes and signs work [5]. Fiske in the book semiotics as communication research (Vera, 2014) signs used or appearing on television shows are interconnected things that cause meaning to form, reality does not just appear by using signs that appear, but is processed through the senses according to the references owned by television viewers, so that the signs that appear can be interpreted differently by different people [12]

Table 2.1. Three Levels of Semiotics According to John Fiske

\begin{tabular}{|c|c|}
\hline Reality Level & $\begin{array}{l}\text { Events that areencoded as } \\
\text { reality - appearance of } \\
\text { clothing, environment, } \\
\text { behavior, conversations, } \\
\text { gestures, expressions, } \\
\text { voices, documents, } \\
\text { interview transcripts, and } \\
\text { so on. }\end{array}$ \\
\hline $\begin{array}{l}\text { Representation } \\
\text { Level }\end{array}$ & $\begin{array}{l}\text { Reality } \\
\text { electronically must be } \\
\text { displayed in technical } \\
\text { codes, such as camera, } \\
\text { lighting, editing, music, } \\
\text { and sound. } \\
\text { In written language, } \\
\text { namely words, sentences, } \\
\text { photos, and graphics. } \\
\text { In the language of images, } \\
\text { there are cameras, lighting, } \\
\text { editing music, and others. } \\
\text { All of these elements are } \\
\text { then transmitted in the form } \\
\text { of representational signs } \\
\text { that can realize characters, } \\
\text { narration, action, dialogue } \\
\text { and settings. }\end{array}$ \\
\hline Ideology Level & $\begin{array}{l}\text { All elements are organized } \\
\text { and categorized in } \\
\text { ideological signs, such as } \\
\text { patriarchy, individualism, } \\
\text { race, class, materialism, } \\
\text { capitalism, and others. }\end{array}$ \\
\hline
\end{tabular}

John Fiske's semiotics is suitable to be used as a theory in seeing the signs that exist in films, because in this theory it dissects all aspects of the film starting from the level of reality, appearance, dress (costume), make. up, environment, behavior, speech, gesture, expression, sound. The level of representation, camera, lighting, editing, music and sound and the level of ideology (individualism, patriarchy, capitalism, materialism and so on).

\subsection{Beauty Standard}

Melliana in her book, Exploring the Body: Women and Beauty Myths, says that beauty comes from the Latin language, bellus which is for women and children. In the 
book Aesthetics, Darsono (2007) argues that beauty is an element of beauty. Beauty is divided into two. First, subjective beauty is the beauty that is visible to the eye when looking. Second, objectively beauty is the beauty in an object that is seen. Darsono also sees that the beauty of women is included in subjective beauty, a beauty that is only visible to the eye. Beauty is a dream for all women, but the meaning of beauty for everyone is different, the concept of beauty in each group can be judged differently depending on how the group views it and mutually agrees [5]. According to Kasiyan in the book Manipulation and Dehumanization of Women in Advertisements (2008), women's bodies are categorized as beautiful not only based on facial beauty, but also synonymous with white, smooth, and firm skin. In addition, the shape of the body that accentuates the curves and hair loss of certain organs has made the standard of beauty developed in society. This causes women to make various efforts to look beautiful in order to be accepted by their environment, ranging from slimming down, using cosmetics, to extreme things in the form of plastic surgery [6]. Outer beauty is beauty from the outside that is physical. People can immediately see, judge, and can also make other people interested without doing further introduction and are the starting capital for women. Beauty can be obtained naturally, but it can also be caused by beauty treatments, such as salon treatments and beauty treatments. Outer beauty is physical beauty in the form of outward appearance in the form of the face and body shape. Inner beauty is beauty that comes from within, this beauty is implicit because it cannot be seen directly with the eye and is usually synonymous with attractiveness. Inner beauty can be known if you have communicated and have deep experience, so that those who say they are beautiful are not themselves, but other people who see them. People who have inner beauty usually have a mediocre appearance, but if you know them better, someone can feel that the person has something interesting, such as behavior or personality [5]. The ideal concept of a beautiful woman in a film certainly uses a female actor as a representation. This female actor acts and acts as a symbol and media text in which it provides meaning for media consumers to negotiate and digest existing personal subjectivities. Celebrities become a representation in people's daily life, including beauty standards. It is not surprising that the celebrities broadcast by the media are celebrities who have ideal height, bright skin, and symmetrical facial shapes. This assumes that the concept of woman is perfect and ideal for everyday life in society [10].

\section{METHOD}

This study uses a qualitative approach using a descriptive format. Qualitative research is research that has the aim of gaining an in-depth understanding of social and human problems by interacting with phenomena. This research does not use data that can be measured statistically, the aim is to explain the findings clearly, in detail, and in detail to answer the problem formulation. The research method used in this study is John Fiske's semiotic analysis (the codes of television) by analyzing three levels, namely the level of reality, the level of representation, and the level of ideology.In this study the writer took the subject of his research is the film Imperfect: Career, Love \& Scales. While the object of this research is the signs of beauty standards that exist in films, which can be in the form of dialogues, characters, and scenes. The data collection process carried out by the author is by conducting interviews with the film director, namely Ernest Prakasa, the next method is, non-participant observation by observing the signs on the film, literature study, and the next data collection is documentation by taking pieces of film scenes for analysis. This process is carried out to obtain data to complement and support the research process in order to get maximum results. The validity technique used in this study was triangulation, namely triangulation of sources by comparing the results of interviews and data that had been collected in harmony or not.

\section{FINDINGS AND DISCUSSIONS}

In this section the writer will describe the results of the analysis of the research and the author's findings that have been obtained based on the results of interviews with informants and non-participatory observations. In the film Imperfect: Career, Love \& Scales.film Imperfect: Career, Love \& Scales is a film adapted from Meira Anastasia's book, which in her book describes how she overcomes insecurities makes and peace with herself.

\subsection{Self-Acceptance}

Champlin (2012) in the journal The Influence of Body Image and Meaningful Behavior on Self-Acceptance in Women says that self-acceptance is an attitude of feeling satisfied with oneself, qualities and talents possessed as well as recognition of one's own limitations [13]

In an online interview with Ernest Prakasa as director of the film Imperfect, having imperfections is not a wrong thing, but if you want to improve yourself with the right goals and without any coercion from other people.

"Theterror of beauty standards follows us, every time we open social media there are beauty standards that haunt women, so I want to address this issue with the perspective that it's ok not to be perfect, but that doesn't mean you shouldn't if you have the desire to improve yourself as long as it is for a good cause or it is not for the purpose of satisfying others.

In this film we arrange it very carefully, perhaps the most appropriate word is careful. For example, we talk about beauty standards, we want to say self-acceptance, that means whatever your condition is, how not ideal you are, it means you don't need to improve yourself, right? and those who do cosmetic surgery to look beautiful wrong? Not like that, if you really feel like improving yourself on your own, not because of pressure from the comments column, not satisfying certain parties, because of yourself, go for it, why not? don't do it for the wrong motivation". 


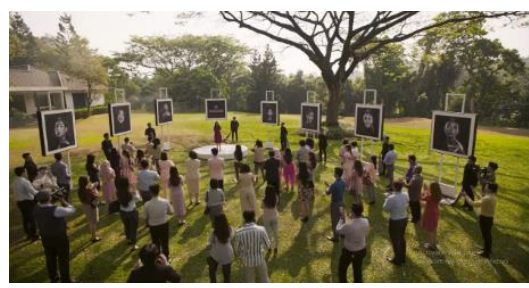

Figure 4.1.1 Rara Introduces Jasmine Company Products

\section{(Source: Netflix.com)}

"So, women are not easy, there are a lot of expectations that weigh on us. Beauty standards that are often unreasonable beauty is slim, beauty is white even though women are very diverse. When this company was founded, Mrs. Melinda chose the name to train not without reason. Training is taken from the Sanskrit language which means good friend and that is our goal for Indonesian women. Good friends don't judge, good friends don't corner, and good friends help us get to know who we really are. And here comes the new face of training".

In this film cut that was taken at 1 hour 43 minutes 15 seconds, Rara as the main character realized that many beauty standards in the environment make women make changes with the wrong motivation so that they can be recognized by the surrounding environment to be the same as the existing beauty standards. Self-acceptance is much influenced by the body image that comes from culture and society's standardization of appearance and beauty, such as the concept of thin, fat, beautiful, and charming when seen. In addition, self-acceptance is also influenced by a person's recognition of himself, it can be in the form of a negative assessment or a positive assessment which later gives a feeling of usefulness and self-worth in living life.

This film cut was taken because the dialogue delivered by Rara portrays acceptance of one's own shortcomings, and makes people who watch it understand that the standardization that exists in society does not guarantee that appearing in accordance with community standards will lead to a happy life.

\subsection{Priority Change}

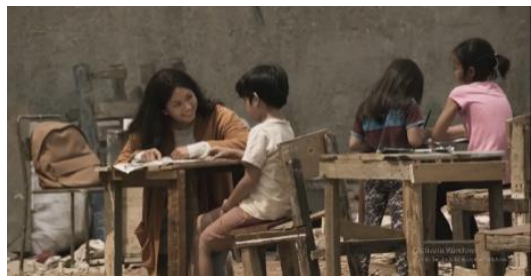

Figure 4.2.1 Rara Before Skinny (Source: Netflix.com)

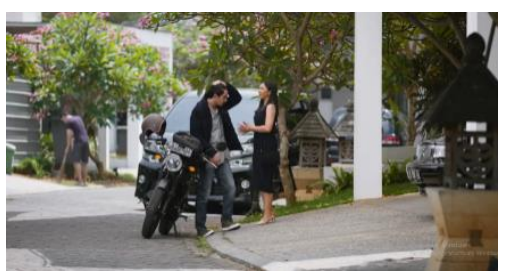

\section{Figure 4.2.2 Rara After Skinny} (Source: Netflix.com)

In the second film Imperfect shows a change in priorities, before Rara experiences weight loss (Figure 4.2.1) in 5 minutes 43 seconds, Rara wears simple and appropriate clothes, and is willing to use a motorbike to go to Lentera school, which is an emergency school. where Rara taught. However, after Rara lost weight (Figure 4.2.2) in 1 hour 15 minutes 10 seconds, Rara's appearance changed drastically from appearance to attitude. Rara attaches importance to her appearance which must be beautiful, even to go to Lentera school, Rara chooses to use vehicles online instead of going with Dika on a motorbike.

"When Rara changed her appearance, what changed was not only her appearance but also her priorities. For the sake of not wanting to be limp he doesn't want to ride Dika's motorbike, he prefers to take a taxi, he gets stuck in traffic and finally teaches him late. It shows that her priorities have changed, not only her appearance has changed but her priorities have also changed, this is one of my ways to give angel that her attitude has shifted, not just her look "

Changes in appearance made by Rara led to changes in attitudes in her daily life. One example is Rara's refusal to go with Dika on a motorbike. This behavior change is a form of priority change that occurred in Rara. The two snippets of pictures were taken because they showed a difference in appearance displayed by the main shop. Apart from that, from the dialogue that was delivered there was also a change so that it showed a change in priority for Rara in the film.

\subsection{Inner Beauty Beats Physical Appearance}

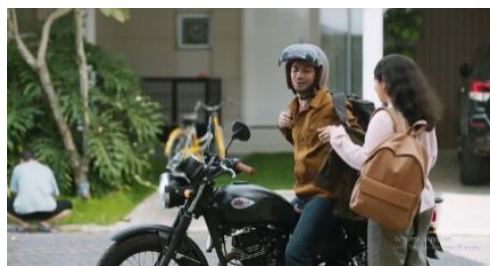

Figure 4.3.1 Rara's First Meeting with Dika at the Lantern School (Source: Netflix.com)

So far, Rara's social environment is more concerned with physical appearance than her behavior. At one point, Rara got the opportunity to be promoted, but she couldn't get the opportunity because her appearance was not in accordance with the standard of beauty in society. This forces Rara to 
make changes in order to accept the position, this change has been responded positively by Rara's environment starting from her family, friends where she works, including her lover.

Physical is one of women's assets to look beautiful, but for Dika, Rara's lover, female beauty is not only physically (Outer Beauty). He also doesn't see women from their physical appearance alone, because according to Dika, personality is important. Personality-related beauty is beauty that is more about character, character or behavior. This beauty is not seen directly by the eye, this beauty is called inner beauty.

"That there is also inner beauty, there are also things that make Dika love Rara, which is not only because of her appearance, because of her care for these children"

The film, which is available at 1 hour 35 minutes 55 seconds, shows Rara's first meeting with Dika at Lentera school. It was Dika's first meeting that made her fall in love with Rara because of her concern for the children at Lentera school, besides that Rara is also a smart woman, regardless of her outer appearance. This film cut is taken because it shows that the inner beauty of a person can be seen from their concern for the environment, and beauty in a woman is not only seen from physical appearance.

\section{CONCLUSIONS}

Based on the data analysis conducted by the author on the film Imperfect: Career, Love \& Scales by using John Fiske's semiotics, it can be seen that there is an attempt to dismantle the stereotype of women's beauty standards which are always based on physical (beauty outer beauty). This can be seen from self-acceptance, changes in priorities starting from appearance and behavior when the main character is still fat who never looks at physical beauty, but when the main character is thin the main actor sees physical beauty as everything, but at the time different main characters realize that physical appearance (outer beauty) is not the main thing for her. The main character evaluates women's inner beauty and self-acceptance is the main thing for her. The standard of beauty shown in this film tries to show that the standard of physical (beauty outer beauty) is not the main thing, the main beauty standard is women who have(inner beauty inner beauty) and also portrays acceptance of one's own shortcomings. The reconstruction of beauty standards in this film is no longer always based on standards of outer beauty physically. A woman who has a look according to beauty standards does not guarantee that she will be happy and will be liked by many people without a good attitude or behavior.

Many women are only concerned with physical beauty and cannot make peace with their physical deficiencies and forget about inner beauty. In this film, it shows that having a fat body can also be accepted by the general public, besides that it wants to reveal that women who look in accordance with existing beauty standards are not always considered beautiful, but women who appear outside of beauty standards can also be considered beautiful and have good behaviour. also shows a good response, film
Imperfect: Career, Love \& Scales breaks the standard of beauty that women always have to have a slim body, this film shows that inner beauty is the main thing that is called beautiful.

\section{ACKNOWLEDGMENT}

The author like to thank all those who helped me in completing this study, the authors also thank the Ernest Initiatives are available as a resource to complement this research data, thanks also to Ahmad Junaidi as a mentor in this study. The author also thanks the faculty of communication science at Tarumanagara University for giving the author the opportunity to complete this research.

\section{REFERENCES}

[1] D. Mulyana, Ilmu komunikasi. 2007.

[2] M. Angela and S. Winduwati, "Representasi Kemiskinan dalam Film Korea Selatan (Analisis Semiotika Model Saussure pada Film Parasite)," Koneksi, vol. 3, no. 2, p. 478, 2020, doi: 10.24912/ kn.v3i2.6480.

[3] D. McQuail, Teori Komunikasi Massa McQuail Edisi 6. 2011.

[4] Eden A. Sitompul and Juni Agus Simaremare, "Analisis Fungsi Nilai Budaya Dan Kearifan Lokal Dalam Film Sinamot Karya Sineas muda Medan : Kajian Antropolinguistik," no. September, pp. 24-37, 2017.

[5] M. Leliani, G. Priyowidodo, M. Wahjudianata, P. Ilmu, U. Kristen, and P. Surabaya, "Representasi kecantikan perempuan korea selatan dalam film ' plump revolution,", 2018.

[6] H. G. Worotitjan, P. I. Komunikasi, and U. K. Petra, "Konstruksi Kecantikan dalam Iklan Kosmetik Wardah,” 2011.

[7] Kompas.com, "Sinopsis Film Imperfect Tayang Hari Ini.” Sembiring, Ira Gita Natalia, 2019.

[8] K. Romli, Komunikasi Massa, no. November 2016. 2017.

[9] A. M. Natalia, "Representasi Kekerasan Simbolik dalam Film Comic 8," J. e-Komunikasi, vol. 3, no. 2, 2015. 
[10] A. Meldina, ““ 200 POUNDS BEAUTY' KARYA KIM YOUNG HWA.,” pp. 1-13, 2015.

[11] S. Winduwati, "Representasi Seks Bebas Pada Lirik Lagu Dangdut (Analisis Semiotika Saussure Pada Lirik Lagu 'Cinta Satu Malam')," J. Muara Ilmu Sos. Humaniora, dan Seni, vol. 1, no. 2, p. 346, 2018, doi: 10.24912/jmishumsen.v1i2.1023.

[12] D. F. R. Puspita and I. K. Nurhayati, "Analisis Semiotika John Fiske Mengenai Realitas Bias Gender Pada Iklan Kisah Ramadhan Line Versi Adzan Ayah," ProTVF, vol. 2, no. 2, p. 157, 2019, doi: 10.24198/ptvf.v2i2.20820.

[13] N. Hasmalawati, "Pengaruh Citra Tubuh Dan Perilaku Makan Terhadap Penerimaan Diri Pada Wanita," J. Psikoislamedia, vol. 2, no. 2, pp. 107-115, 2017. 